\title{
Seasonal contrasts in diurnal carbon incorporation by phytoplankton size classes of the coastal plume of Chesapeake Bay*
}

\author{
Thomas W. Jones ${ }^{1,2}$, Thomas C. Malone ${ }^{2}$, Sherry Pike ${ }^{2}$ \\ ${ }^{1}$ Salisbury State University, Department of Biological Sciences, Salisbury, Maryland 21801, USA \\ ${ }^{2}$ Horn Point Environmental Laboratories, University of Maryland, PO Box 775, Cambridge, Maryland 21613, USA
}

\begin{abstract}
Diurnal variations in patterns of carbon fixation by phytoplankton size classes in the coastal plume of the Chesapeake Bay were compared during seasonal extremes in freshwater flow and nutrient discharge. The diurnal mean chlorophyll-specific productivity $\left(\mathrm{P}^{\mathrm{B}}\right)$ for net and nanoplankton was correlated closely to temperature with the amplitude of diurnal variation in $\mathrm{P}^{\mathrm{B}}$ being minimal in April, higher in June, and maximal in August for both size classes. However, nanoplankton $\mathrm{P}^{\mathrm{B}}$ increased more rapidly and was significantly higher than netplankton $\mathrm{P}^{\mathrm{B}}$ in August. Biomass carbohydrate/protein ratios were consistently higher in netplankton than in nanoplankton and from April to August the magnitude of the ratio decreased for both size classes ( 2.35 to 1.23 and 0.85 to 0.58 , respectively). Carbon incorporation into biochemical fractions was significantly correlated with productivity. Carbon incorporation into protein and polysaccharide exhibited greater diurnal periodicity during June and August when $\mathrm{P}^{\mathrm{B}}$ was correlated to solar radiation, respectively decreasing and increasing with increasing radiation during both months and in both size classes. Diurnal polysaccharide synthesis was highest relative to productivity in nanoplankton during June when nanoplankton dominated the phytoplankton biomass, and likewise, netplankton polysaccharide synthesis was highest during August when netplankton dominated. Results suggest that these high diurnal rates of polysaccharide synthesis set the stage for higher rates of nocturnal protein synthesis and biomass production by nanoplankton during June and by netplankton during August.
\end{abstract}

\section{INTRODUCTION}

Natural assemblages of phytoplankton exhibit diurnal photosynthetic periodicity (e.g. Sournia 1974) the amplitude and phasing of which has been shown to be influenced by light and nutrients (e.g. Newhouse et al. 1967, Hitchcock 1978, Barlow 1982, Prézelin et al. 1987). Phytoplankton size structure is also an important factor. Size classes of phytoplankton exhibit different patterns of diurnal periodicity depending on environmental conditions. Under oligotrophic conditions, nanoplankton from surface waters has been shown to peak earlier in the photoperiod than netplankton (Malone 1971, Paerl \& MacKenzie 1977, Prézelin et al. 1987). Such size-dependent effects are not as evident in eutrophic coastal environments where photosynthesis often reaches peak capacity at midday (MacCaull \& Platt 1977, Malone 1982). Size-dependent effects of

- UMCEES Contribution no. 2158 nutrient depletion have been documented in the coastal plume of the Hudson River, New York, USA (Malone et al. 1980). Nanoplankton and netplankton both exhibited midday peaks in chlorophyll a specific, lightsaturated photosynthesis $\left(\mathrm{P}_{\mathrm{M}}^{\mathrm{B}}\right)$ during the development of a bloom of netplankton diatoms Asterionella japonica. Netplankton $\mathrm{P}_{\mathrm{M}}^{\mathrm{B}}$ exceeded that of the nanoplankton during this period. As the concentration of dissolved silicate decreased below $1.0 \mu \mathrm{g}$-at. $\mathrm{l}^{-1}$, the amplitude of the netplankton diurnal cycle decreased and $\mathrm{P}_{\mathrm{M}}^{\mathrm{B}}$ peaked earlier in the photoperiod. Nanoplankton $\mathrm{P}_{\mathrm{M}}^{\mathrm{B}}$ was unaffected and increased with temperature to rates substantially greater than netplankton $\mathrm{P}_{\mathrm{M}}^{\mathrm{B}}$.

Such differences in the amplitude and phasing of diurnal variations in photosynthesis should be related to daily growth rate and to patterns of carbon incorporation into cellular pools of protein, polysaccharide, and other biochemical constituents. In general, carbon incorporation into protein is less responsive to shortterm environmental variability and more closely 
related to growth rate than is carbon incorporation into other biochemical constituents (for reviews see Morris 1980, 1981). Carbon incorporation into protein typically occurs throughout the light-dark cycle with nocturnal protein synthesis occurring at the expense of polysaccharide synthesized during the previous photoperiod (Cosper 1982, Priscu \& Goldman 1983, Barlow 1984c, Cuhel et al. 1984, Lancelot \& Mathot 1985, Hitchcock 1986, Harding \& Jones 1988). These observations suggest that high diurnal $\mathrm{P}_{\mathrm{M}}^{\mathrm{B}}$ and carbon incorporation into storage reserves may enhance nocturnal protein synthesis leading to greater biomass production on time scales longer than $24 \mathrm{~h}$. Thus, the dominance of a given size class of phytoplankton might be expected to be related to the ability of that size class to achieve higher diurnal rates of carbon incorporation into polysaccharide and other storage reserves (Morris 1980, Malone 1982). Such difference in productivity patterns and time-dependent changes in photosynthesis-light relationships have led to the suggestion that netplankton possess metabolic capabilities which enable them to achieve higher growth rates than nanoplankton in turbulent environments (Malone 1982, Barlow 1984a, b).

The purpose of this study was to determine the extent to which and under what conditions phytoplankton size classes exhibit different diurnal patterns of photosynthesis and carbon incorporation into biochemical constituents. The work was conducted in the coastal plume of the Chesapeake Bay, USA, during seasonal periods of contrasting phytoplankton size structure.

\section{MATERIALS AND METHODS}

Study site and sampling methods. The diurnal studies presented here were made during cruises on the RV 'Gyre' in the plume of the Chesapeake Bay during June and August 1985 and April 1986 (Fig. 1). The diurnal variations were determined using timeseries studies while following surface drifters deployed near the mouth of the Bay during ebb tides. Normally the time-series studies lasted for 30 to $40 \mathrm{~h}$ with some as long as $51 \mathrm{~h}$. During each of the nearly month-long sampling periods from 4 to 6 time-series experiments were conducted. At approximately sunrise, 09:00, $12: 30$, and 16:00 h of each sampling day, the ship was positioned next to the drogue and surface water was collected with 301 Niskin bottles attached to the ship's CTD (conductivity-temperature-depth) array. Water from the bottles was screened through $202 \mu \mathrm{m}$ mesh Nitex prior to placement in bottles which had been washed 3 times with sample water.

Physical and chemical measurements. Water temperature and salinity were obtained during drifter studies from both the ship's CTD system and an onboard computer-controlled thermosalinograph monitoring system using continuously flowing water from either the ship's hull pump while underway or the CTD while on station. Total daily photosynthetically active radiation (PAR) was measured using a Licor Model LI1776 solar monitor. Concentrations of dissolved inorganic nutrients $\left(\mathrm{NH}_{4}-\mathrm{N}, \mathrm{NO}_{3}-\mathrm{N}, \mathrm{NO}_{2}-\mathrm{N}, \mathrm{PO}_{4}-\mathrm{P}\right.$, and $\mathrm{SiO}_{4}-\mathrm{Si}$ ) were determined on a Technicon AutoAnalyzer II.

Biomass measurements. All water samples for determining biomass were separated by size into a whole water and $\mathrm{a}<10 \mu \mathrm{m}$ fraction by parallel filtrations of water through both a Whatman GF/F glass fiber filter (whole water) and through a $10 \mu \mathrm{m}$ Nitex screen (by gravity) onto a GF/F filter (nanoplankton). GF/F filtrations were under vacuum at $<100 \mathrm{~mm} \mathrm{Hg}$. The biomass in the $>10 \mu \mathrm{m}$ fraction (netplankton) was calculated as the difference between the whole water and the $<10 \mu \mathrm{m}$ fraction.

Chlorophyll concentrations (chl) were determined aboard ship by the fluorometric method of Yentsch \& Menzel (1963), filtering 140 to $280 \mathrm{ml}$ onto $25 \mathrm{~mm}$ Whatman GF/F glass fiber filters. Whole water samples were preserved in Lugol's solution for phytoplankton taxonomic analysis using the inverted microscope technique.

Samples for protein and carbohydrate analyses were filtered (500 to $1000 \mathrm{ml}$ ) onto precombusted $47 \mathrm{~mm}$ Whatman GF/F filters and stored at $-20^{\circ} \mathrm{C}$ until analyzed. Protein and carbohydrate extractions were as in the ${ }^{14} \mathrm{C}$ biochemical fractionation procedure described below with the only variation being that the filters containing protein were extracted in $0.5 \mathrm{~N} \mathrm{NaOH}$ at $100^{\circ} \mathrm{C}$ for $10 \mathrm{~min}$. Carbohydrate extracts were analyzed by the phenol-sulfuric acid method of Dubois et al. (1956) using a glucose standard. Protein was determined by the Folin-Ciocalteau method (Lowry et al. 1951) with reagent concentrations as in Dorsey et al. (1977) using bovine serum albumin as a standard.

The following assumptions were made in calculating the carbon content of protein and carbohydrate to compare carbon flow into these compounds with the total amounts present: (1) protein carbon was calculated as $50 \%$ of total protein weight; (2) carbohydrate carbon was calculated as $40 \%$ of total carbohydrate weight.

${ }^{14} \mathrm{C}$-assimilation and biochemical fractionation. Water samples collected in Niskin bottles from the surface were used to fill duplicate $250 \mathrm{ml}$ polycarbonate bottles and 75 to $100 \mu \mathrm{Ci}$ of $\mathrm{NaH}^{14} \mathrm{CO}_{3}$ was added. The samples were incubated for ca $3 \mathrm{~h}$ in an ondeck incubator using neutral density screening to obtain 50 to $70 \%$ incident solar irradiance and surface seawater was used to maintain ambient temperature. Diurnal incubations were conducted in a sequential manner 
Fig. 1. Study site. Enclosed area approximates location of drogue studies with months indicating more specific locations

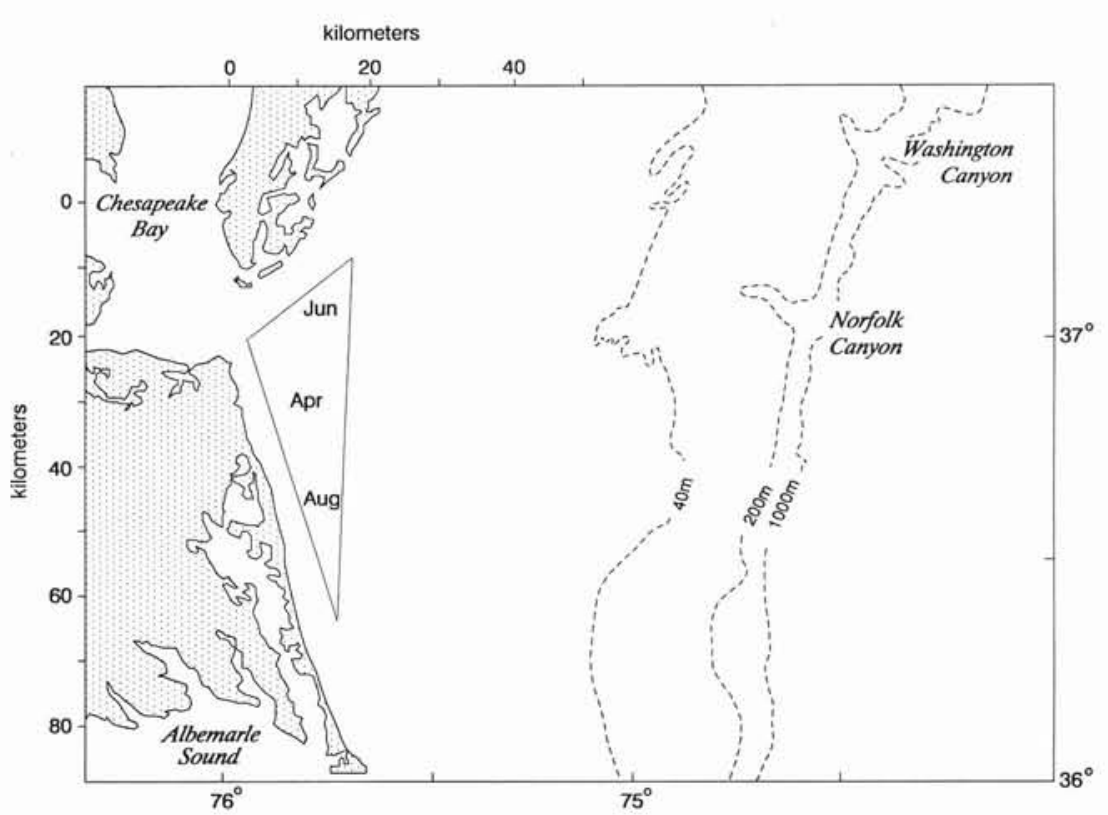

starting at $06: 00$ to $06: 30 \mathrm{~h}$ with the maximum time between incubations never being more than $30 \mathrm{~min}$.

Following incubation, each sample was subdivided into 2 fractions: a $25 \mathrm{ml}$ aliquot for determination of total ${ }^{14} \mathrm{C}$-uptake (TA) and a $100 \mathrm{ml}$ aliquot for biochemical fractionation (BF). Both fractions were gravityscreened through $10 \mu \mathrm{m}$ Nitex onto $25 \mathrm{~mm}$ GF/F filters (nanoplankton) and the $10 \mu \mathrm{m}$ Nitex gently backwashed onto another set of $25 \mathrm{~mm} \mathrm{GF/F}$ filters using freshly filtered seawater (netplankton). All GF/F's were vacuum-filtered ( $<100 \mathrm{~mm} \mathrm{Hg}$ ) and washed with 3 aliquots of freshly filtered seawater. Filters for TA were placed into $20 \mathrm{ml}$ plastic scintillation vials and $30 \mu \mathrm{l}$ of glacial acetic acid added directly onto the filter. After $10 \mathrm{~min}, 10 \mathrm{ml}$ of Beckman Redi-Solv HP was added.

The BF filters were placed directly into $20 \mathrm{ml}$ glass scintillation vials and stored frozen until analysis for the distribution of ${ }^{14} \mathrm{C}$ in biochemical components according to the method of $\mathrm{Li}$ et al. (1980). This method partitions cellular macromolecules into functional groups; an aqueous methanol-soluble fraction (low molecular weight metabolites), a chloroform-soluble fraction (lipid), a hot $5 \%$ trichloroacetic acid-soluble fraction (polysaccharide and nucleic acids), and a hot $5 \%$ trichloroacetic acid-insoluble fraction (protein). Lipid (LIP) and low molecular weight metabolites (LMW) were extracted with chloroform/methanol/ water (3:3:2.7, respectively); the chloroform and methanol-water layers were separated by centrifugation. Protein (PRO) and polysaccharide (POL) were extracted with $4 \mathrm{ml}$ of hot $5 \%$ trichloroacetic at $95^{\circ} \mathrm{C}$ for $30 \mathrm{~min}$ followed by a wash of $4 \mathrm{ml}$ of cold $5 \%$ trichloroacetic acid. To minimize quench during scintillation counting, $1 \mathrm{ml}$ aliquots of LIP extract were dried at room temperature in $20 \mathrm{ml}$ glass scintillation vials and $5 \mathrm{ml}$ of Aquasol-2 (New England Nuclear) were added. For both the POL and LMW samples, $1 \mathrm{ml}$ aliquots of extract were placed in $20 \mathrm{ml}$ glass scintillation vials and $10 \mathrm{ml}$ of Aquasol-2 were added. The filters containing the protein were placed in $20 \mathrm{ml}$ glass scintillation vials and $10 \mathrm{ml}$ of Aquasol- 2 were added.

When considering the ratio of carbohydrate to protein the following terminology is used here: in terms of biomass, 'carbohydrate/protein' is used and in terms of assimilation of carbon 'polysaccharide/protein' is used. While extraction protocols for these biochemical groups were nearly the same, the quantification methods employed were not (e.g. glucose and bovine serum albumin used as standards in the spectrophotometric procedures for biomass measurements of carbohydrate and protein, respectively, and the quantity of ${ }^{14} \mathrm{C}$ in the fractions used in the assimilation measurements).

Radiation counting. All samples were measured for radioactivity using an LKB Model 1217 liquid scintillation counter. Measured radioactivity was corrected for quench by using an internal standard and channels ratio method. A separate quench correction was used for each solvent and scintillation fluor.

\section{RESULTS AND DISCUSSION}

\section{Environmental conditions}

Freshwater discharge $\left(Q_{\mathrm{f}}\right)$ from the Bay decreased from April to August while incident radiation and temperature increased (Table 1). Ambient concen- 
Table 1. Mean and range of surface water physical and chemical characteristics during incubations. $\mathrm{I}_{0}$ : incubation intensity $\left(\mu\right.$ Einst. $\left.\mathrm{m}^{-2} \mathrm{~s}^{-1}\right) ; \mathrm{T}$ : temperature $\left({ }^{\circ} \mathrm{C}\right) ; \mathrm{Q}_{\mathrm{f}}$ : monthly freshwater flow for the previous month, $\left(\times 10^{8} \mathrm{~m}^{3} \mathrm{~d}^{-1}\right) ; \mathrm{N}$ : total dissolved inorganic nitrogen $\left(\mu \mathrm{g}\right.$-at. $\left.1^{-1}\right)$; P: dissolved orthophosphate $\left(\mu \mathrm{g}\right.$-at. $\left.1^{-1}\right) ;$ Si: dissolved silicate $\left(\mu \mathrm{g}\right.$-at. $\left.1^{-1}\right)$

\begin{tabular}{|c|c|c|c|c|c|c|}
\hline & \multicolumn{2}{|c|}{$\begin{array}{c}\text { April } \\
\text { Mean Range }\end{array}$} & \multicolumn{2}{|c|}{$\begin{array}{c}\text { June } \\
\text { Mean Range }\end{array}$} & \multicolumn{2}{|c|}{$\begin{array}{c}\text { August } \\
\text { Mean Range }\end{array}$} \\
\hline $\mathrm{I}_{0}$ & 299 & $\begin{array}{r}80 \\
969\end{array}$ & 343 & $\begin{array}{r}59 \\
928\end{array}$ & 501 & $\begin{array}{r}86 \\
921\end{array}$ \\
\hline $\mathrm{T}$ & 11.4 & $\begin{array}{l}10.0 \\
12.9\end{array}$ & 21.0 & $\begin{array}{l}19.7 \\
22.6\end{array}$ & 26.0 & $\begin{array}{l}25.3 \\
28.5\end{array}$ \\
\hline$Q_{f}$ & 4.1 & & 1.4 & & 0.6 & \\
\hline $\mathrm{N}$ & 2.4 & $\begin{array}{l}0.6 \\
4.0\end{array}$ & 0.3 & $\begin{array}{l}0.2 \\
0.4\end{array}$ & 0.3 & $\begin{array}{l}0.2 \\
0.4\end{array}$ \\
\hline $\mathrm{P}$ & 0.4 & $\begin{array}{l}0.3 \\
0.4\end{array}$ & 0.5 & $\begin{array}{l}0.5 \\
0.6\end{array}$ & 0.5 & $\begin{array}{l}0.5 \\
0.5\end{array}$ \\
\hline $\mathrm{Si}$ & 0.8 & $\begin{array}{l}0.4 \\
1.5 \\
\end{array}$ & 1.6 & $\begin{array}{l}1.1 \\
2.6\end{array}$ & 1.7 & $\begin{array}{l}1.0 \\
2.4\end{array}$ \\
\hline $\mathrm{N} / \mathrm{Si} / \mathrm{P}$ & $6 /$ & $2 / 1$ & $0.6 /$ & $3.2 / 1$ & $0.6 /$ & $3.4 / 1$ \\
\hline
\end{tabular}

trations of dissolved inorganic nutrients also varied between seasons (Table 1) with $\mathrm{N}$ concentration being highest in April when $\mathrm{Q}_{\mathrm{f}}$ was high and Si concentration being highest in August when $Q_{i}$ was low. Based on an $\mathrm{N}: \mathrm{Si}: \mathrm{P}$ radio of $16: 16: 1$ for nutrient-replete diatoms, $\mathrm{Si}$ was depleted relative to $\mathrm{N}$ and $\mathrm{P}$ in April and $\mathrm{N}$ was depleted relative to $\mathrm{Si}$ and $\mathrm{P}$ in June and August. These trends in nutrient concentration are consistent with patterns of nutrient input, uptake and recycling within Chesapeake Bay (McCarthy et al. 1977, D'Elia et al. 1986, Fisher et al. 1988). Export of $\mathrm{NO}_{3}-\mathrm{N}$ is greatest during spring when freshwater runoff peaks while $\mathrm{PO}_{4}$ $\mathrm{P}$ and $\mathrm{SiO}_{4}-\mathrm{Si}$ export is greatest during summer when sediment release peaks.

\section{Productivity and biomass}

Chlorophyll-specific productivity $\left(\mathrm{P}^{\mathrm{B}}\right)$ of both size classes increased from an April minimum to an August maximum (Table 2). Nanoplankton chlorophyll a (chl) concentration was highest in April while netplankton chl was highest in August. Nanoplankton dominated in June in terms of both $\mathrm{P}^{\mathrm{B}}$ and chl due to the abundance of cyanobacteria, microflagellates, and small centric diatoms. Netplankton dominated in August due primarily to the abundance of diatoms (Skeletonema costatum and Chaetoceros spp.) and secondarily to dinoflagellates (Gymnodinium spp.).

Biomass carbohydrate/protein (CAR/PRO) ratios were consistently higher in netplankton than in nanoplankton during all 3 seasons (Table 2). The protein- rich status of nanoplankton relative to netplankton may be related to size and floristic composition (e.g. Hitchcock 1982) or to the presence of nutrient-deficient netplankton populations (Myklestad \& Haug 1978, Barlow 1980). While the biomass ratio decreased in both size classes from April to August, the assimilation ratio, polysaccharide/protein (POL/PRO) (calculated from Table 4), increased.

Malone \& Ducklow (1990) present data on the relationship of phytoplankton biomass to bacterioplankton biomass during this same time period in the Chesapeake plume. They found that phytoplankton biomass declined relative to bacterioplankton biomass from April to August, and concomitantly, the turnover rate of particulate organic carbon (POC) increased. This reported shift in an autotroph-dominated biomass system in the spring to a heterotroph-dominated biomass system in the summer is further supported by our data on the opposing trends in the CAR/PRO and POL/ PRO ratios. As the protein-rich bacterioplankton biomass increased in the summer, the biomass CAR/PRO ratio decreased. As $\mathrm{N}$ decreased and became limiting for the polysaccharide-producing phytoplankton biomass in the summer, the POL/PRO assimilation ratio increased. These trends were most pronounced in the netplankton population.

\section{Diurnal photosynthesis and carbon incorporation patterns}

The amplitude of diurnal variations in $\mathrm{P}^{\mathrm{B}}$ was minimal in April, higher in June, and maximal in August (Fig. 2). Such increases in diurnal periodicity with increasing daily radiation are characteristic of natural phytoplankton assemblages (cf. Doty \& Oguri 1957. Lorenzen 1963). As indicated by least squares regressions of $\mathrm{P}^{\mathrm{B}}$ on incident radiation $\left(\mathrm{I}_{0}\right)$ (Table 3$), \mathrm{P}^{\mathrm{B}}$ was unrelated to $\mathrm{I}_{0}$ in April and highly correlated in August. Nanoplankton and netplankton $\mathrm{P}^{\mathrm{B}}$ increased with $\mathrm{I}_{0}$ at about the same rate in June, but nanoplankton increased more rapidly and was significantly $(\mathrm{p}<0.01)$ higher than netplankton in August.

During April, the partitioning of carbon among biochemical fractions showed little diurnal variability except in the LIP fraction where incorporation tended to increase during the photoperiod (Fig. 3). Carbon incorporation into each biochemical fraction was significantly correlated with productivity, and carbon incorporation into PRO and POL increased at equivalent rates within each size class (Table 4 ). The proportion of carbon incorporation into PRO and POL exhibited greater diurnal periodicity during June and August when $\mathrm{P}^{\mathrm{B}}$ was correlated with $\mathrm{I}_{0}$ (Figs. 4 \& 5). Carbon incorporation into PRO and POL respectively 
Table 2. Mean biomass and coefficient of variation (CV) values for nanoplankton $(<10 \mu \mathrm{m})$ and netplankton $(>10 \mu \mathrm{m})$.

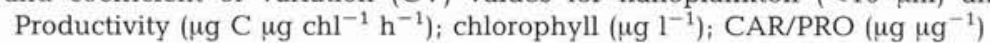

\begin{tabular}{|c|c|c|c|c|c|c|c|}
\hline \multirow[t]{2}{*}{ Period } & & \multicolumn{2}{|c|}{ Productivity } & \multicolumn{2}{|c|}{ Chlorophyll } & \multicolumn{2}{|c|}{ CAR/PRO } \\
\hline & & Mean & $\mathrm{CV}$ & Mean & $\mathrm{CV}$ & Mean & $\mathrm{CV}$ \\
\hline April & $\begin{array}{l}<10 \mu \mathrm{m} \\
>10 \mu \mathrm{m}\end{array}$ & $\begin{array}{l}3.65 \\
2.73\end{array}$ & $\begin{array}{l}30 \% \\
53 \%\end{array}$ & $\begin{array}{l}3.44 \\
2.70\end{array}$ & $\begin{array}{l}43 \% \\
59 \%\end{array}$ & $\begin{array}{l}0.85 \\
2.35\end{array}$ & $\begin{array}{l}28 \% \\
42 \%\end{array}$ \\
\hline June & $\begin{array}{l}<10 \mu \mathrm{m} \\
>10 \mu \mathrm{m}\end{array}$ & $\begin{array}{l}7.38 \\
2.95\end{array}$ & $\begin{array}{l}63 \% \\
75 \%\end{array}$ & $\begin{array}{l}1.59 \\
0.72\end{array}$ & $\begin{array}{l}22 \% \\
36 \%\end{array}$ & $\begin{array}{l}0.67 \\
1.78\end{array}$ & $\begin{array}{l}36 \% \\
55 \%\end{array}$ \\
\hline August & $\begin{array}{l}<10 \mu \mathrm{m} \\
>10 \mu \mathrm{m}\end{array}$ & $\begin{array}{l}13.96 \\
20.25\end{array}$ & $\begin{array}{l}67 \% \\
82 \%\end{array}$ & $\begin{array}{l}0.92 \\
2.42\end{array}$ & $\begin{array}{l}45 \% \\
68 \%\end{array}$ & $\begin{array}{l}0.58 \\
1.23\end{array}$ & $\begin{array}{l}41 \% \\
49 \%\end{array}$ \\
\hline
\end{tabular}

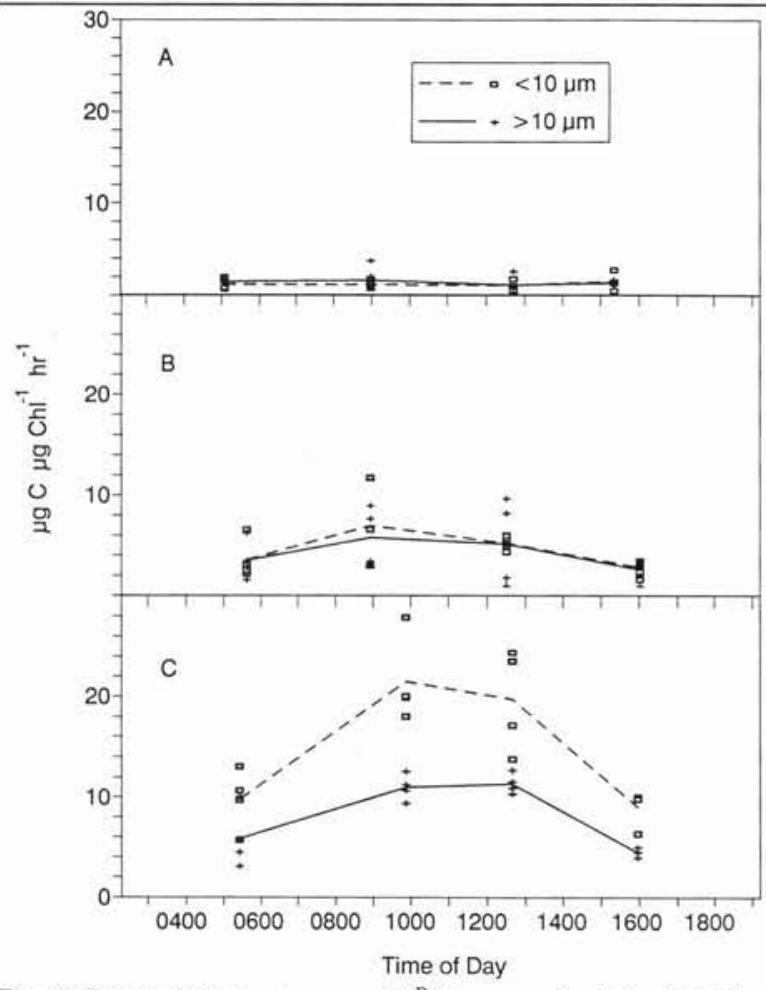

Fig. 2. Diurnal time-courses of $\mathrm{P}^{\mathrm{B}}$ for nanoplankton $(<10 \mu \mathrm{m})$ and netplankton (>10 $\mathrm{m}$ ) in (A) April, (B) June, and (C) August. Data points at each time of day are from different days

Table 3. Summary regression statistics for linear relationships between productivity $\left(\mathrm{P}^{\mathrm{B}}\right)$ and incubation radiation $\left(\mathrm{I}_{0}\right)$ for nanoplankton $(<10 \mu \mathrm{m})$ and netplankton $(>10 \mu \mathrm{m})$. Values in parentheses are standard errors

\begin{tabular}{|lccccc|}
\hline Period & Intercept & Slope & $\mathrm{r}^{2}$ & $\mathrm{n}$ \\
\hline $\begin{array}{l}\text { April } \\
<10 \mu \mathrm{m}\end{array}$ & $1.4(0.6)$ & $-0.001(0.003)$ & 0.02 & 17 \\
$\quad>10 \mu \mathrm{m}$ & $0.7(0.8)$ & $0.006(0.003)$ & 0.16 & 17 \\
$\begin{array}{l}\text { June } \\
<10 \mu \mathrm{m}\end{array}$ & $2.5(2.0)$ & $0.010(0.003)$ & 0.38 & 18 \\
$>10 \mu \mathrm{m}$ & $2.2(2.4)$ & $0.010(0.004)$ & 0.30 & 18 \\
$\begin{array}{l}\text { August } \\
<10 \mu \mathrm{m}\end{array}$ & $5.6(3.0)$ & $0.027(0.003)$ & 0.82 & 16 \\
$>10 \mu \mathrm{m}$ & $3.1(1.3)$ & $0.015(0.001)$ & 0.88 & 16 \\
\hline
\end{tabular}

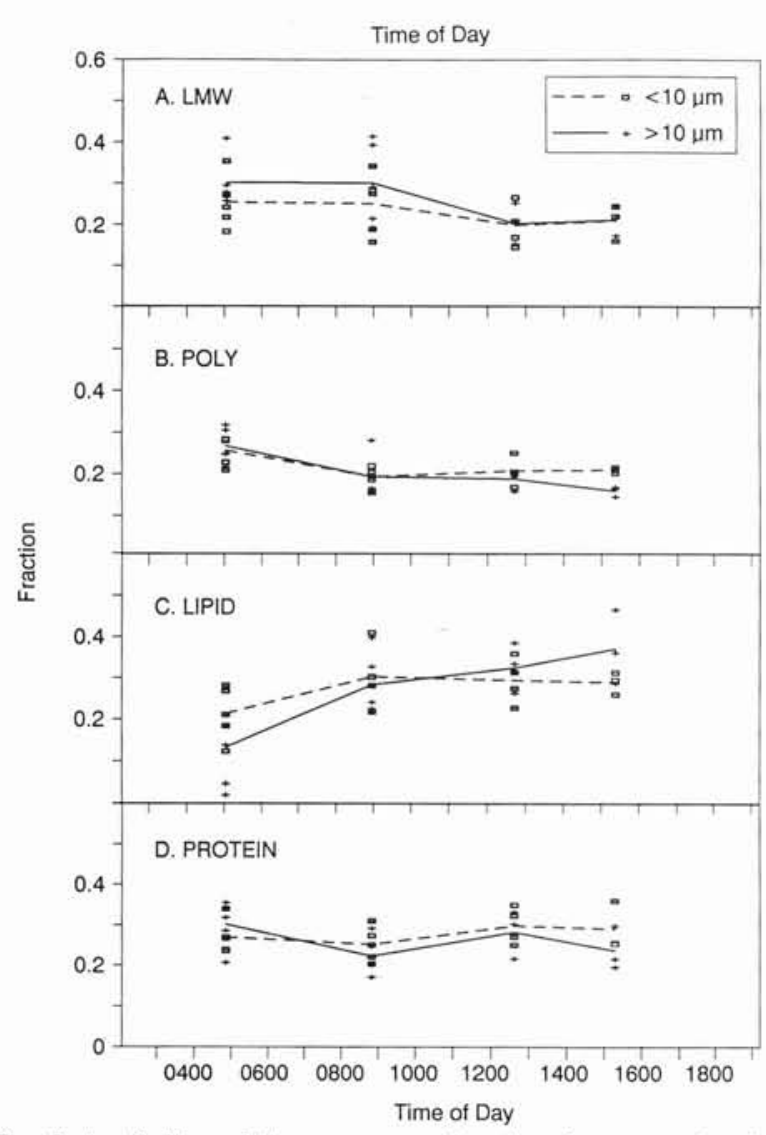

Fig. 3. April diurnal time-courses of carbon incorporation into (A) low-molecular-weight compounds, (B) polysaccharides, (C) lipids, and (D) proteins as a fraction of the total carbon incorporation for nanoplankton $(<10 \mu \mathrm{m})$ and netplankton $(>10 \mu \mathrm{m})$. Data points at each time of day are from different days

decreased and increased with increasing $\mathrm{I}_{0}$ during both months and in both size classes. Carbon incorporation into LMW and LIP pools showed little diurnal variability although carbon incorporation into the LMW pool was substantially higher in netplankton during June (Fig. 4a). In contrast to June when nanoplankton carbon incorporation into POL was highest and increased most rapidly with productivity, carbon incorporation into POL in netplankton was highest and increased 
Table 4. Slopes of linear regressions of the percentage incorporation of carbon into biochemical fractions versus total carbon incorporation for nanoplankton $(<10 \mu \mathrm{m})$ and netplankton $(>10 \mu \mathrm{m})$. Values in parentheses are standard errors. All regressions are highly significant $(\mathrm{p}<0.001)$ and intercepts not significantly different from 0

\begin{tabular}{|cccccc|}
\hline & \multicolumn{2}{c}{ April } & June & August \\
\hline$<10 \mu \mathrm{m}$ LMW & $0.26(0.05)$ & $0.13(0.01)$ & $0.28(0.02)$ \\
LIP & $0.32(0.06)$ & $0.14(0.01)$ & $0.21(0.01)$ \\
POL & $0.18(0.03)$ & $0.54(0.03)$ & $0.34(0.01)$ \\
PRO & $0.23(0.04)$ & $0.20(0.03)$ & $0.17(0.02)$ \\
$>10 \mu \mathrm{m}$ & & & & & \\
LMW & $0.30(0.03)$ & $0.29(0.02)$ & $0.23(0.02)$ \\
LIP & $0.10(0.05)$ & $0.19(0.01)$ & $0.15(0.01)$ \\
POL & $0.28(0.02)$ & $0.36(0.02)$ & $0.55(0.02)$ \\
PRO & $0.32(0.03)$ & $0.16(0.02)$ & $0.07(0.02)$ \\
\hline
\end{tabular}

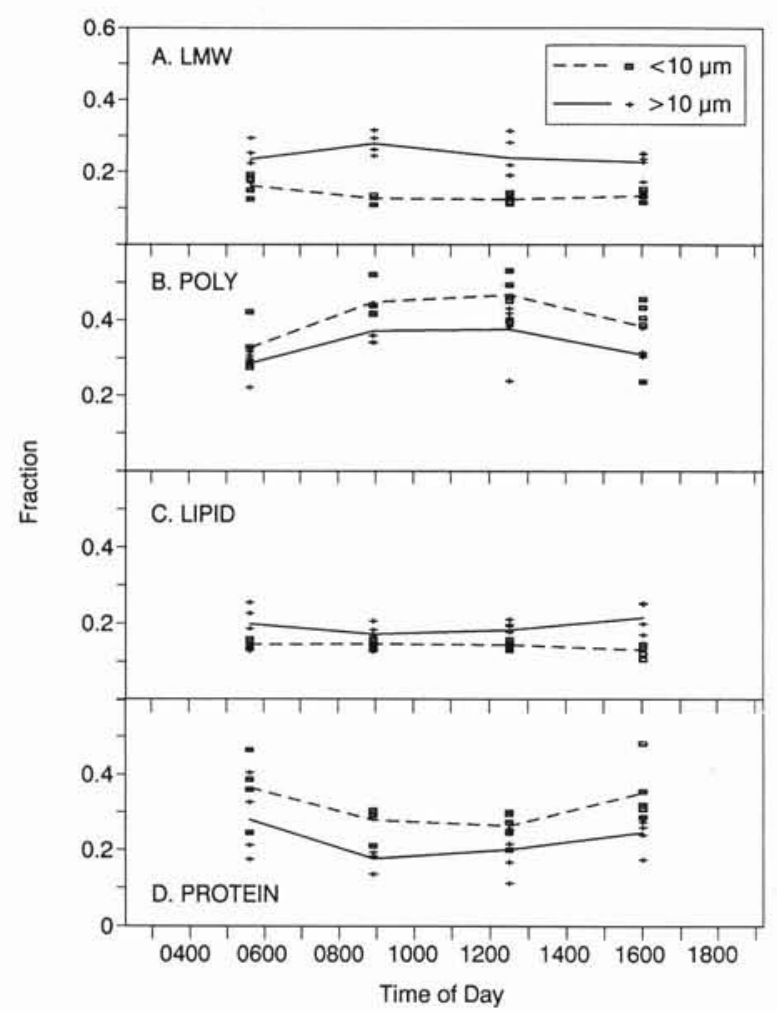

Fig. 4. June diurnal time-courses of carbon incorporation into (A) low-molecular-weight compounds, (B) polysaccharides, (C) lipids, and (D) proteins as a fraction of the total carbon incorporation for nanoplankton $(<10 \mu \mathrm{m})$ and netplankton $(>10 \mu \mathrm{m})$. Data points at each time of day are from different days

most rapidly during August (Table 4). Nanoplankton carbon incorporation into PRO relative to productivity showed little seasonal variability while netplankton incorporation declined from a maximum of $32 \%$ in April to $7 \%$ in August (Table 4). Such a decrease in carbon incorporation into PRO with increasing light has been described for phytoplankton from a variety of environments (Morris \& Skea 1978, Li et al. 1980, Barlow 1982). As a consequence of the selective decline in netplankton observed here, netplankton carbon incorporation into PRO was lower than nanoplankton during June and August, and the POL/PRO incorporation ratio was higher and increased more rapidly with increasing productivity in netplankton than in

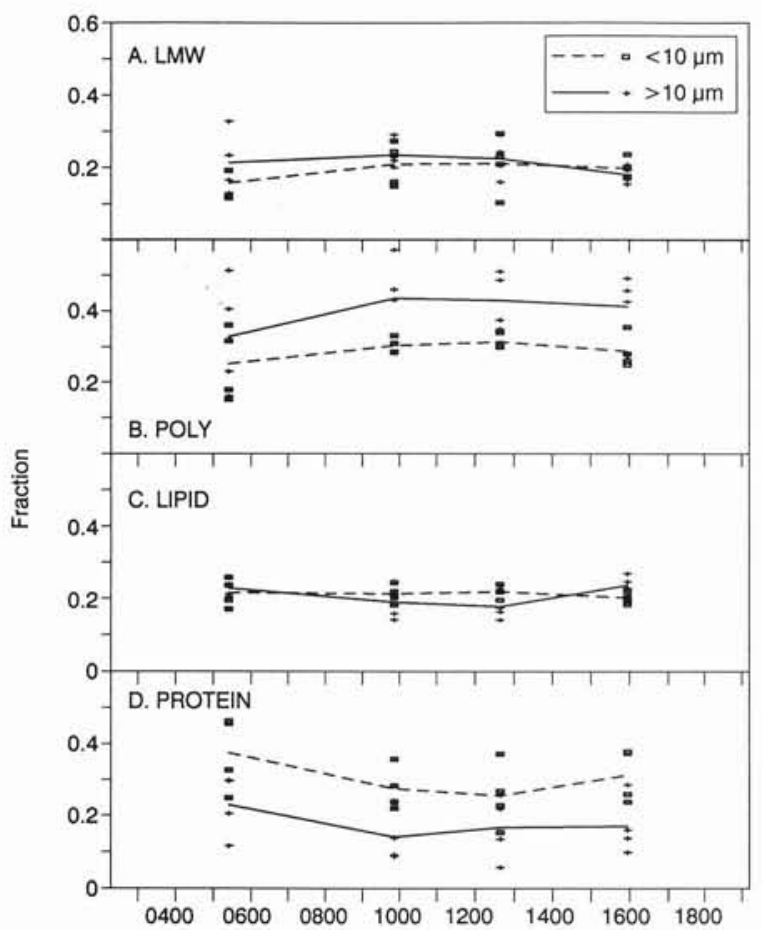

Fig. 5. August diurnal time-courses of carbon incorporation into (A) low-molecular-weight compounds, (B) polysaccharides, (C) lipids, and (D) proteins as a fraction of the total carbon incorporation for nanoplankton $(<10 \mu \mathrm{m})$ and netplankton $(>10 \mu \mathrm{m})$. Data points at each time of day are from different days

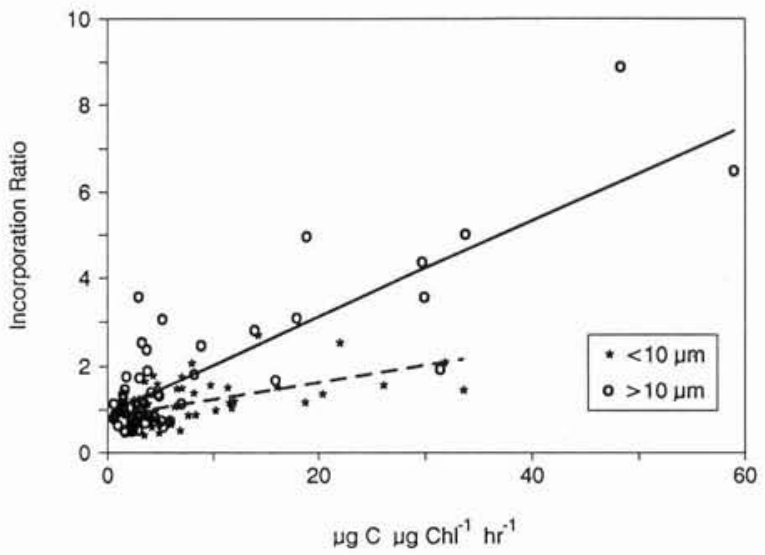

Fig. 6. Relationship of the polysaccharide to protein ratio (incorporation ratio) to $\mathrm{P}^{\mathrm{B}}$ for all data in nanoplankton $(<10$ $\mu \mathrm{m})$ and netplankton $(>10 \mu \mathrm{m})$ 
nanoplankton (Fig. 6). It is unlikely that these patterns of $\mathrm{P}^{\mathrm{B}}$ variability and differences among size classes were related to the release of dissolved organic ${ }^{14} \mathrm{C}$ since rates of release were generally less than $10 \%$ of total fixation and were inversely related to $\mathrm{P}^{\mathrm{B}}$ (Ducklow, Malone \& Pike unpubl.).

Malone \& Ducklow (1990) found phytoplankton populations of the Chesapeake plume to be in a state of perpetual decline due to mixing with phytoplanktonpoor coastal water in April and to the selective loss of netplankton diatoms in June and August. Glibert (pers. comm.) also found no indication of a strong preference for any given form of dissolved inorganic nitrogen during June and August and concluded that phytoplankton from the plume were probably $\mathrm{N}$-deficient. These results, the depletion of $\mathrm{N}$ relative to $\mathrm{P}$ and $\mathrm{Si}$ in the ambient nutrient pool, and low concentrations of dissolved inorganic $\mathrm{N}$ suggest that phytoplankton growth was N-limited during June and August. Comparison of CAR/PRO biomass ratios suggest that netplankton were $\mathrm{N}$-deficient relative to nanoplankton (Table 2) which were characterized by ratios typical of nutrient sufficient phytoplankton (Myklestad \& Haug 1978, Barlow 1980). POL/PRO incorporation ratios are consistent with this interpretation and indicate, as found by Barlow (1982), that netplankton diatoms have a greater capacity to synthesize storage reserves than do nanoplankton. Diurnal POL synthesis was highest relative to productivity in nanoplankton during June when nanoplankton accounted for most phytoplankton biomass and productivity (Table 4). Likewise, netplankton POL synthesis was highest during August when netplankton dominated. In both cases, CAR/PRO biomass ratios were less than diurnal incorporation ratios and fluctuated around 1. Barlow (1982) also found that natural populations of phytoplankton in the Benguela Upwelling region assimilated the largest proportion of carbon into POL during periods of increased carbon assimilation and active growth and the most into PRO during periods of reduced carbon assimilation and no growth. Assuming that biomass ratios reflect nutrient history over a generation or more (Hitchcock 1978, Morris \& Skea 1978), these results imply that high diurnal rates of POL synthesis set the stage for higher nocturnal rates of PRO synthesis and biomass production by nanoplankton during June and by netplankton during August.

Acknowledgements. This research was supported by grants from the Biological Oceanography division of the National Science Foundation (OCE 84-06526 and OCE 87-16909). We are grateful to the crew of the RV 'Gyre' for their patience and skill during this study and a special thank you is extended to Brian Wendler for technical assistance and labor. Nutrient data was kindly provided by C. Garside.

\section{LITERATURE CITED}

Barlow, R. G. (1980). The biochemical composition of phytoplankton in an upwelling region off South Africa. J. exp. mar. Biol. Ecol. 45: 83-93

Barlow, R. G. (1982). Phytoplankton ecology in the Southern Benguela current. II. Carbon assimilation patterns. J. exp. mar. Biol. Ecol. 63: 229-237

Barlow, R. G. (1984a). Dynamics of the decline of a phytoplankton bloom after an upwelling event. Mar. Ecol. Prog. Ser. 16: 121-126

Barlow, R. G. (1984b). Physiological responses of phytoplankton to turbulent and stable environments in an upwelling region. J. Plankton Res. 6: 385-397

Barlow, R. G. (1984c). Time-series uptake of carbon into photosynthetic products of Benguela phytoplankton populations. J. Plankton Res. 6: 435-442

Cosper, E. (1982). Influence of light intensity on diel variations in rates of growth, respiration, and organic release of a marine diatom: comparison of diurnally constant and fluctuating light. J. Plankton Res. 4: 705-724

Cuhel, R. L., Ortner, P. B., Lean, D. R. S. (1984). Night synthesis of protein by algae. Limnol. Oceanogr. 29: 731-744

D'Elia, C. F., Sanders, J. G., Boynton, W. R. (1986). Nutrient enrichment studies in a coastal plain estuary: phytoplankton growth in large-scale, continuous cultures. Can. J. Fish. Aquat. Sci. 43: 397-406

Dorsey, T. E., McDonald, P. W., Raoels, O. A. (1977). A heated biuret-Folin protein assay which gives equal absorbance with different proteins. Analyt. Biochem. 78: 156-164

Doty, M. S., Oguri, M. (1957). Evidence for a photosynthetic daily periodicity. Limnol. Oceanogr, 2:37-40

Dubois, M., Gilles, K. A., Hamilton, J. K., Rebers, P. A., Smith, F. (1956). Colorimetric method for determination of sugars and related methods. Analyt. Chem. 28: 230-256

Fisher, T. R., Harding, L. W., Stanley, D. W., Ward, L. G. (1988). Phytoplankton, nutrients, and turbidity in the Chesapeake, Delaware, and Hudson estuaries. Estuar. coast. Shelf Sci. 27: 61-93

Harding, L. W., Jones, T. W. (1988). Carbon metabolism in estuarine phytoplankton: regulation of photosynthetic fixation patterns. Biol. Oceanogr. 5: 183-214

Hitchcock, G. L. (1978). Labelling patterns of carbon-14 in net plankton during a winter-spring bloom. J. exp. mar. Biol. Ecol. 31: 141-153

Hitchcock, G. L. (1986). Methodological aspects of time course measurements of ${ }^{14} \mathrm{C}$ fixation in marine phytoplankton. J. exp. mar. Biol. Ecol. 96: 233-243

Lancelot, C., Mathot, S. (1985). Biochemical fractionation of primary production by phytoplankton in Belgian coastal waters during short- and long-term incubations with ${ }^{14} \mathrm{C}$ bicarbonate. I. Mixed diatom population. Mar. Biol. 86: 219-226

Li, W. K., Glover, H. E., Morris, I. (1980). Physiology of carbon photoassimilation by Oscillatoria thiebautii in the Caribbean Sea. Limnol. Oceanogr. 25: 447-456

Lorenzen, C. J. (1963). Diurnal variation in photosynthetic activity of natural populations. Limnol. Oceanogr. 8: 56-62

Lowry, O. H., Rosebrough, N. J., Farr, A. L., Randall, R. J. (1951). Protein measurement with Folin phenol reagent. J. biol. Chem. 193: 265-267

MacCaull, W. A., Platt, T. (1977). Diel variations in the photosynthetic parameters of coastal marine phytoplankton. Limnol. Oceanogr. 22: 723-731

Malone, T. C. (1971). Diurnal rhythms in netplankton and nanoplankton assimilation ratios. Mar. Biol. 10: 285-289

Malone, T. C. (1982). Phytoplankton photosynthesis and car- 
bon-specific growth: light-saturated rates in a nutrientrich environment. Limnol. Oceanogr. 27: 226-235

Malone, T. C., Ducklow, H. W. (1990). Microbial biomass in the coastal plume of the Chesapeake Bay: phytoplanktonbacterioplankton relationships. Limnol. Oceanogr. 35: 296-312

Malone, T. C., Garside, C., Neale, P. J. (1980). Effects of silicon depletion on photosynthesis by diatoms in the plume of the Hudson River. Mar. Biol. 58: 197-204

McCarthy, J. J., Taylor, W. R., Taft, J. L. (1977). Nitrogenous nutrition of the plankton in Chesapeake Bay. 1. Nutrient availability and phytoplankton preferences. Limnol. Oceanogr. 22: 996-1011

Morris, I. (1980). Paths of carbon assimilation in marine phytoplankton. In: Falkowski, P. G. (ed.) Phytoplankton productivity in the sea. Plenum Press, New York, p. 139-159

Morris, I. (1981). Photosynthesis products, physiological state, and phytoplankton growth. in: Platt, T. (ed.) Physiological bases of phytoplankton ecology. Can. Bull. Fish. Aquat. Sci. 210: 83-102

Morris, I., Skea, W. (1978). Products of photosynthesis in natural populations of marine phytoplankton from the Gulf of Maine. Mar. Biol. 47: 303-312

This article was presented by Professor K. R. Tenore, Solomons, Maryland, USA
Myklestad, S., Haug, A. (1972). Production of carbohydrates by the marine diatom Chaetoceros affinis var. willei (Gran) Hustedt. I. Effect of the concentration of nutrients in the culture medium. J. exp. mar. Biol. Ecol. 9: 125-136

Newhouse, J., Doty, M.S ., Tsuda, R. T. (1967). Some diurnal features of a neritic surface plankton population. Limnol. Oceanogr. 12: 207-212

Paerl, H. W., Mackenzie, L. A. (1977). A comparative study of the diurnal carbon fixation patterns of nanoplankton and net plankton. Limnol. Oceanogr. 22: 732-737

Prézelin, B. B., Bidigare, R. R., Matlick, H. A., Putt, M., Ver Hoven, B. (1987). Diurnal patterns of size-fractionated primary productivity across a coastal front. Mar. Biol. 96: 563-574

Priscu, J. C., Goldman, C. R. (1983). Carboxylating enzyme activity and photosynthetic endproducts of phytoplankton in the shallow and deep chlorophyll layers of Castle Lake. Limnol. Oceanogr. 28: 1168-1181

Sournia, A. (1974). Circadian periodicities in natural populations of marine phytoplankton. Adv. mar. Biol. 12: 325-389

Yentsch, C. S., Menzel, D. W. (1963). A method for the determination of phytoplankton chlorophyll and phaeophytin by fluorescence. Deep Sea Res. 10: 443-448

Manuscript first received: April 27, 1990

Revised version accepted: August 30, 1990 